\title{
Online Referrals Categorization and Performance of the Hospitality Industry: The Case of International Hotel Brands in Europe
}

\author{
Iva Slivar $^{\mathrm{a}} \quad$ Ramazan Ufuk Bayer ${ }^{\mathrm{b}}$
}

\begin{abstract}
When mentioning online referrals in tourism, the first associations for most are online reviews of guests, usually those on the most popular social media website in tourism - TripAdvisor. In fact, online referrals ${ }^{1}$ are a much broader concept which is presented through their categorization according to their affiliation to e-marketing domains. The goal of this paper is to research the use of online referrals in hospitality according to the suggested classification. A research featuring a selection of European branded hotel chains, ranging from luxury to budget, and their use of online referrals is presented. The results revealed that most hotels have an average performance in online referrals marketing as a whole, while hotels classified in the budget segment show the worst performance.
\end{abstract}

Keywords: Referral Marketing, International Hotel Brands in Europe, Affiliate Marketing, Guest Reviews, Social Media

JEL Classification: M31, L82, L83

\section{Introduction}

Technological enhancements, especially the internet and mobile devices have been reshaping the world and marketing as well. Today, all communication directions in terms of business (B2B, B2C, C2C, C2B) are possible within the virtual environment. Digital media is a new avenue to retain existing customers and acquire new customers for marketers. Numerous business fields have been affected by technological changes and the tourism industry as well. Tourism is highly affected by these developments since tourists have a high tendency of using digital platforms and tourism is an information-intensive industry (Poon, 1993; Sheldon, 1997). Tourists' purchases and the whole information search behavior are being digitalized. As Schueckert, Liu and Law (2015: 608) stated that 71\% of independent tourists make their hotel bookings online. These figures demonstrated that virtual channels dominate the tourism distribution system. Although tourists make their hotel bookings offline, they may use the internet for gathering information about hospitality establishments. Gretzel and Yoo (2008: 39) have found out that $96.4 \%$ of the frequent internet users consult online tourists' reviews while they are planning their trips. Also, another research showed that $49 \%$ of potential tourists won't make their hotel reservations without reading online tourist reviews (Statisticbrain, 2014). Thus, keeping up with new media has become indispensable for hospitality managements.

People today can be defined as cyber citizens because they spend more and more of their time in digital environments. As Wertime and Fenwick (2008) stated, the boundaries of physical and virtual begin to blur. Also, markets begin to digitalize in parallel with the digitalization of the human lives. Therefore,

${ }^{a}$ Asst. Prof., Juraj Dobrila University of Pula, Faculty of Economics and Tourism “Dr. Mijo Mirković", Preradovićeva 1, 52100 Pula, Hrvatska, iva.slivar@unipu.hr

bPhD. Student, Anadolu University, Institute of Social Sciences, Eskisehir, Turkiye, r.ufukbayer@gmail.com 
marketers have to focus on virtual markets in addition to physical markets. In other words, companies are competing with them both in the physical and virtual markets. There is a huge potential in the virtual world for marketers and if they omit this to target this market, they will pay a heavy price for such their unsuccessful strategies. In this context, there is an old statement "fish where the fish are" which may guide marketers.

This research simply broadens the understanding of online reviews in hospitality. The aim of this research is to evaluate current online marketing performance of international hotel brands in Europe by adopting a holistic approach. As Wang and Tang (2003: 14) highlighted that further empirical research and theoretical development are necessary for understanding online marketing better. Also, Cantallops and Salvo (2014) have published a literature review article which classified the researches under two categories as "review-generating" and "impact of e-wom". It can be observed that the subjects like how frequently consumers use digital sources, to what extend they are affected, why they share information in these environments and similar - are broadly investigated in the literature. Although researchers have focused on the subject in terms of demand-side in their researches, it is possible to say that they don't pay enough attention to the supply-side. This research may be thought to be important due to its contribution on the supply-related side of the subject. This paper is composed of six parts. In the theoretical review part, conceptual aspect of the subject is explained and a review of literature is given. The proposed model of classification of online referrals is presented in part three. In the fourth part, selected European hotel chains' use of online marketing in a certain point of time is provided. The fifth part provides the results followed by concluding remarks.

\section{Literature Review}

\subsection{Online Reviews}

It is known that the internet is one of the digital areas affected by rapid changes. Web 2.0 or social media technology is a milestone in the history of internet's development. There is no need to discuss how web 2.0 technology has reshaped the digital platforms. Web 2.0 is absolutely a great evolution in the internet technology. As Kaplan and Haenlein (2010: 60) underlined that "Is social media just old wine in new bottles?" and the answer is probably not. This technological advancement has transformed the one-way communications (monologue) into two-way interactions (dialogues). In the past, web content was published by the website owner only, visitors could just view the web page and couldn't do more. Content creation in the web was freed from the monopoly of the marketers with the rising of social media. Individuals have gained power in terms of information production and distribution (Xiang and Gretzel, 2010: 179). Information taking place in the digital world is explained with the phrase as "wisdom of crowds" due to its collaborative structure (Pearse, 2007: 16). In other words, information in the digital environment has been democratized.

The advancements mentioned above have led to some fundamental changes in marketing. WOM (Word of Mouth) which is an essential communication type of marketing has gained a new form as "e-wom". Ordinary people can be heard in the digital world. The change is easy as typing "e" in front of the abbreviation of "WOM" morphologically. In fact, the invisible part of the iceberg is so deep. Chatterjee (2001) differentiated online WOM from its offline form in that there is no need to share any social ties between communicators, it is a kind of many-to-many communication and has a high speed of dissemination. Besides these differences, customers find e-WOM less trustworthy than its traditional form. DeMatos and Rossi (2008) suggested that e-WOM is less trustable due to its source credibility and non-existing or weak social ties between the receiver and the source of the message. Although e-WOM is founded less trustable than the traditional WOM, customers find the information generated by other customers more credible than the information generated by marketers (Smith, Menon \& Sivakumar, 2005: 17) and potential customers trust and are influenced by the content created by other customers (Yoo and Gretzel, 2010; Cox, et al., 2011). Potential tourists perceive the content generated by other tourists useful because it provides advantages like reducing their costs (time, effort etc.) and post-purchase dissonance (Litvin, et al., 2008: 466; Cantallops and Salvo, 2014: 41). Although there is a consensus on the explanation about the subject, most researchers prefer to use different terms for referring this communication. It is possible to encounter the terms like; user- 
generated content (UGC), user-created content (UCC), consumer-generated media (CGM), online reviews, online recommendations, online referrals, guest comments, word-of-mouse in the literature (Stringam and Gerdes, 2010; Filieri and McLeay, 2013; Cantallops and Salvo, 2014).

The first example of information production in the digital media is encountered in the hospitality industry. We began to see guestbook applications on hotels' own webpages. Later on, tourists become more powerful to share their own thoughts on digital space with the proliferation of social media. It can be said that tourists' experiences are getting increasingly transparent in consequence of tourists' shares about their holidays on social media. Also, information produced by tourists is perceived as preferable by potential tourists because they want to get objective opinions without any commercial concern (Schuckert, et al., 2015: 609). Furthermore, contents shared by tourists is unfiltered or uncensored in social media and thus, this kind of information regarded as objective (Jeong and Jeon, 2008: 124). Gretzel and Yoo (2008: 40) revealed that potential tourists find the information produced by other tourists as enjoyable and up-to-date. On the other hand, some characteristics (intangible, complex and experiential) of tourism products and services make such information more valuable (Bansal and Voyer, 2000; Chung and Buhalis, 2008; O'Connor, 2008; Litvin and Hoffman, 2012). Tourists' motivation on reading online tourists reviews is increased by another point that purchasing tourism products and services is a kind of high involvement purchase and is perceived as highly risky (Park, et al., 2007; Litvin and Hoffman, 2012). Potential tourists read such information in order to reduce the uncertainty. As Bickart and Schindler (2001) stated that online review readers almost gain indirect experience (Gretzel and Yoo, 2008). Lastly, as Chatterjee (2001) indicated, consumers give more importance to the other customers' considerations when a consumer is unfamiliar with a service provider, which is often the case for travel-related decisions. These reasons may help to understand tourists' increasing tendency on consulting the information produced by other tourists. Information produced by tourists is one of the most frequently consulted source in the tourism and especially in the hospitality field (Gretzel and Yoo, 2008; Filieri and McLeay, 2013). Gretzel and Yoo (2010) gauged the similar parameters with their research published in 2008 and came to the conclusion that the impact of tourist generated content on tourist decision making has increased in two years. Gretzel and Yoo (2008) also highlighted how online tourist review readers is an important target market for tourism industry because they have high income, education level and travel frequency.

New technology has affected both the distribution system of tourism and tourists' travel planning cycle especially their information search behavior (Xiang and Gretzel, 2010; Cantallops and Salvo, 2014: 41). Popularity of user generated content is an indisputable fact today. Furthermore, this kind of information's importance and value have been continuing to rise (Cox et. al., 2009; Litvin and Hoffman, 2012). Therefore, tourism managements and especially hospitality enterprises must integrate new media channels into their marketing strategies. In today's fierce competition environment, establishments have the chance to gain competitive advantages through adopting this new media earlier. On the other hand, new media is an appropriate channel for the hospitality organizations regardless of their size (for both small, medium and large). Moreover, potential tourists perceive that online reviews have a greater impact on their hotel choice decisions while they are searching information about lesser-known hotels rather than well-known hotels (Vermeulen and Seegers, 2009). Social media is a very precious information source for hospitality managers helping them assess and develop their performance in addition to its impact on potential tourists (Schucker, et al., 2015: 609). If hospitality managers observe what guests talk about their facilities on social media, they will understand their performance from the standpoint of their guests. As Chan and Guillet (2011: 349) emphasized that listening the customer in social media is a kind of market research for hospitality marketers. Listening the customers from online broadcast is a more reliable way to get their data rather than a classical survey-based market research because customers share their experiences voluntarily (Jeong and Jeon, 2008). However, it is an insufficient management approach to use this channel passively just for listening the customers. Unfortunately, one of the primary mistakes done by hospitality managements with regard to use of social media is inadequate interaction with their guests and being unresponsive in this channel (Chan and Guillet, 2011: 361-362). If hospitality managements don't respond the tourists' feedbacks and stay inactive in this channel, tourist who shared feedback will think that hospitality managements don't take care of them. Hospitality managers should pay attention to responding especially the negative tourist reviews. Litvin and 
Hoffman's (2012) research revealed that if hotel managements response the negative reviews, this will positively influence the review readers' attitudes toward those hotels. Hotel managements should never forget that digital media is become popular because it enables two-way communication and so marketers have to interact with their guests in this platform (O'Connor, 2008: 757; Kaplan and Haenlein, 2010: 66). As Buhalis and Law (2008) stated that new tourists expect to interact with suppliers to satisfy their own specific needs and wishes.

\subsection{Referral Marketing}

Referral marketing is defined as "a process of developing business networks through which information flows to prospective customers whereby clients are produced with little or no overt marketing activities" (Ugbah and Evuleocha, 2007: 51). Referral marketing is a way of acquiring new customers for companies by harnessing their existing customers. Referral marketing is a kind of stimulated (marketerdirected) WOM which benefits the existing customers' social networks so as to attract new customers (Kumar, et al., 2010; Schmitt, et al., 2011). Referral programs are suitable for three types of market/company; small establishment because of their limited marketing budgets, for niche markets and especially for the companies that sell high-risk goods and services (Berman, 2016: 20). It is known that tourists are taking highrisks while purchasing tourism services and so applying successful referral programs plays a key role for both increasing the current customers' loyalty (Garnefeld, et al., 2013) and attracting new targeted customers to the tourism companies (Schmitt, et al., 2011). Furthermore, Schmitt et. al. (2011) have showed that referral marketing is more valuable way to acquire new customers than other ways because of its cost savings and the similarity between existing customers and new customers-focus on a narrower market segments. Consumers support their purchase decisions with referrals (Cheung, et al., 2014: 295). Referral information has higher credibility than traditional marketing like paid advertisement (Berman, 2016: 19) because there is a close relation between source of information and receiver. Although few companies had tried to benefit from referral programs in the past (Buttle, 1998: 241), marketing managers have become conscious about the importance of referral marketing since the advent of internet. As the internet changes the patterns of most of the things, it has changed the traditional referral marketing and generated its online form. Companies have got into difficulties of information flows in the digital spaces (Dellarocas, 2003) because of the changes in the information production power in favor of the users. In fact, companies have chance to manage the content about their establishments. Looker, Rockland and Taylor-Ketchum (2007) expressed that information in the digital world cannot be controlled but it can be managed. Such developments have made the referral marketing more important because it gives companies opportunities to manage the referral programs and control over the customers' message contents (Schmitt et. al., 2011; Berman, 2016: 19).

Marketers develop different kind of referral programs especially making the most of technological opportunities. Although there are different types of online referral marketing applications, the most useful one is "recommend friends" program (Verlegh, et al., 2013: 670). For instance, as Xia, Tang and Wirtz (2011) indicated; "recommend a friend program" searched in the Google and it was yielded over 70 million hits in 2012. A more recent search on Bing for "recommend a friend program" yielded over 19 million hits (Berman, 2016: 20). These figures show its current importance and it has a promising future as well. On the other hand, it contains some disadvantageous. As Lewis has found out (2006), referral marketing is seen less trustworthy than organic WOM. Although the most reliable data about goods and services is generated by existing customers to potential consumers, online information created within referral programs has no such credibility because these are stimulated by marketers with some incentives. Apart from these, there are some researches about the incentives/rewards design in the referral programs in the marketing literature as well (Biyalogorsky, et al., 2001; Kornish and Li, 2010; Xia et. al. 2011).

\subsection{Affiliate Marketing}

Affiliate marketing is regarded as a marketing approach that has raised from technological advances. Therefore, researchers and marketers have started to discover this so-called new marketing application. Despite it has its origins from in the past, new forms of it become popular contemporarily. However, many 
marketers don't know affiliate marketing adequately (Duffy, 2005: 161) and there is just a few study about this issue in the literature (Mariussen, et al., 2010: 1707). Consequently, it is possible to say that the sufficient level of attention hasn't been paid to this subject by neither researchers nor marketers.

Some researchers bring the term of affiliate marketing to forefront with just its online form but in fact it means more. As Ryan and Jones (2009) pointed out that affiliate marketing is neither a new nor a webbased-only practice. Affiliate marketing has existed prior to the internet with its offline form. For instance, global distribution systems (GDS) has been used in the airlines, hotels and some other tourism companies as offline affiliation before the world wide web (Mariussen et. al., 2010). In addition to this, some concierge services (e.g.: making restaurant reservations for hotel guests) in hotels is an example of offline affiliate marketing as well. Indeed, affiliate marketing has become widespread with the advent of internet (Mariussen, 2012: 31). Even in the definitions of affiliate marketing, the importance of the internet for this marketing application is emphasized. Hoffmann and Novak define affiliate marketing as "the online act of promoting someone else's goods and services to earn commissions from sales leads provided". According to Mariussen (2012), affiliate marketing is based on the premise of cooperation between a business and its affiliates, where a commission is paid to affiliates each time they achieved predefined actions. There are some different types of commission like pay-per-sale, pay-per-lead, pay-per-click etc. (Bandyopadhyay, et al., 2009: 4-5). Basically, affiliate marketing is getting into win-win partnerships.

Affiliate marketing provides advantages in terms of generating more revenue, minimizing costs, lowering wastages, increasing brand awareness, improving website rankings in search engines and etc. for the companies (Daniele, et al., 2009; Gregori, et al., 2014). It is known that most of the sales in tourism industry are realized in the online environment. Affiliate marketing has an important place for the tourism industry. However, the disadvantageous of this marketing practice should not be ignored. Management's direct control power is decreased due to the effect of intermediaries. For this reason, customers may have negative attitudes towards the companies. Another issue is double content in terms of SEO (Search Engine Optimisation), reffered to as "affiliate spam".

\subsection{Model of Classification of Online Referrals in Hospitality}

It is our suggestion to use the term "mentions" to indicate when a hotel company appears online. It can be positive, negative or neutral. It doesn't have to be related to any kind of referrals - it can be mentioned in the press (non-sponsored, not advertorial), enumerated in a scientific article etc. Online referrals are a sub type of mentions.

Online referral is an umbrella term for online marketing tools and techniques that imply the engagement of customers and non-intermediate partners sharing their approval or disapproval, as opposed to acknowledgements and awards by jury experts, certifications of professional institutions and other publicity and PR tactics that use medias. There are two main groups of online referrals: those that are business initiated and the peer-to-peer types. The business initiated types function implies some sort of giving: financial (affiliate marketing) or on a quid pro quo basis (in case of referral marketing). The peer to peer types (online reviews) do not imply any sort of getting something in return.

The proposed model broadens the notion of online reviews in hospitality by crossing those to emarketing domains and thus provides a new framework of relations among known tools and techniques. The focus is on sales-oriented marketing tools (online reviews) and techniques (referral marketing and affiliate marketing). 
Table 1. Categorization of Online Referrals in Hospitality According to e-Marketing Domains

\begin{tabular}{lcc}
\hline & Targeted to Customers & Targeted to Business \\
\hline Business Initiated & $B 2 C$ & $B 2 B$ \\
Customer Initiated & $\begin{array}{c}\text { Referral Marketing } \\
\text { Online reviews on } \\
\text { independent platforms (e.g. } \\
\text { TripAdvisor) }\end{array}$ & $\begin{array}{c}\text { Online reviews, guest books } \\
\text { on hotel platforms }\end{array}$ \\
\hline
\end{tabular}

Source: Authors' Contribution

As shown in Table 1. A referral initiated by business and aimed to their customers in order to attract new leads is known as "referral marketing". Affiliate marketing is a business to business marketing technique oriented to generating more leads, subscribers, sales etc. Business initiated referrals online usually include a link and grade in terms of the emotion carried from positive to neutral.

Customer initiated referrals span emotionally from positive to negative and don't imply the existence of a link. Both positive and negative customer referrals take the form of reviews online as they actually reflect the experience of previous stays. Positive customer initiated online referrals are known as recommendations. The $\mathrm{C} 2 \mathrm{C}$ category is the most widely known forms of reviews having TripAdvisor as its main representative. Customer initiated negative feedback is not so often publicly available online on hotel's platforms. Online guest books as modules of hotel websites are not a popular functionality, however some hoteliers, aware of the importance of references in the selling process, are publishing selected reviews of guests on their websites or using mash up-s (integrating reviews automatically) from TripAdvisor and similar social rating websites. Hotels also collect feedback from direct guests who booked online within their after staying messaging.

\section{Research}

The research is based on the above mentioned new classification of online referrals in tourism. The sample of hotel chains was intentional, taken from the report "The European hotel industry" and includes 66 hotel chains. These hotels were used as benchmarks in the above mentioned report, in order to classify and count existing European hotels. The sample is presented in table 2.

Table 2. Sample of Selected European Hotel Chains

\begin{tabular}{ccccc}
\hline Deluxe & Up-Market & Mid-Market & Economy & Budget \\
\hline Conrad & Clarion & Country Inn by Carlson & Bastion & Etap \\
Four Seasons & Crowne Plaza & Courtyard by Marriott & Bleu Marine & Formula 1 \\
Kempinski & De Vere & Express by Holiday Inn & Campanille & Premiere Class \\
Luxury Collection & Firmdale & Forum & Comfort & Balladins \\
Manderin & Grand Hyatt & Four Points & Days Inn & Ibis \\
Orient Express & Intercontinental & Holiday Inn & Inkeepers Lodge \\
Park Hyatt & Jolly Master & Holiday Inn Garden & Kyriad \\
Raffles & Le Meridien & Court & Nulte d'hotel \\
Ritz-Carlton & Maritim & Howard Johnson & Premier Lodge \\
Rocco Forte Hotels & Marriott & Jolly Classic & Sleep Inn \\
Savoy Group & Mella & Moat House & Travel Inn \\
St Regis & Millennium & Novotel & Travelodge \\
& Radisson & Quality & Wetherlodge \\
& Renaissance & Ramada & \\
& Shangri-La & Scnadic & \\
& Sheraton & Sol & \\
& Sofitel & Suite Hotels & \\
& Swissotel & & \\
\hline
\end{tabular}

Source: "The European Hotel Industry" . Retrieved from:

http://www.otusco.com/Otus\%20Hotel\%20Analyst\%20Size\%20and\%20Structure\%201.pdf 
The empirical research was carried out in December 2014. It was investigated, by observation of hotel official websites, whether or not hotels of a certain chain used affiliate marketing (usually as a link in secondary navigation known sometimes as partner program), referral marketing ("tell a friend" link or "Share" button on various social media websites) or if they published guest reviews on their websites/used a guestbook (although an outdated functionality, it was still included in the research).

In the case of online reviews on social rating websites/social guides, TripAdvisor, as the most prominent representative was chosen. Only in case hoteliers answered to posted reviews in public it was taken in account as if they used this communication strategy. The authors' researched the last five reviews of hotels under a certain brand in search for management responses.

In case hotels displayed also links to their profiles/pages on social media networks on their official websites, it was also recorded. The coding system used was rather simple: in case a certain strategy was used, it was coded as 1 , if not, it was counted as 0.

A fifth category, unrelated to online referral classification - presence on social media - was also investigated. It was coded as 1 if there were any social media links displayed.

\section{Results}

The results of use of referrals by hoteliers in Europe will be presented by categories of hotels and in total.

Table 3. Online Referrals Use by Luxury European Hotels

\begin{tabular}{r|cccccc}
\hline \multicolumn{1}{c}{ Brands } & Referral & $\begin{array}{c}\text { Affiliate } \\
\text { Program }\end{array}$ & $\begin{array}{c}\text { Reviews } \\
\text { on } \\
\text { Website }\end{array}$ & $\begin{array}{c}\text { Presence } \\
\text { in Social } \\
\text { Media }\end{array}$ & $\begin{array}{c}\text { Review } \\
\text { Answer on } \\
\text { Tripadvisor }\end{array}$ & Total \\
\hline $\begin{array}{r}\text { Conrad } \\
\text { Mandarin } \\
\text { Oriental }\end{array}$ & NO & NO & NO & YES & YES & 2 \\
Rocco Forte & NO & NO & NO & YES & YES & 2 \\
Park Hyatt & NO & YES & NO & NO & YES & 1 \\
Four Seasons & YES & NO & NO & YES & NO & 1 \\
Luxury Collection & NO & YES & YES & YES & YES & 3 \\
Orient Express & NO & NO & NO & YES & YES & 2 \\
Raffles & NO & YES & NO & YES & YES & 3 \\
Ritz-Carlton & NO & NO & NO & YES & YES & 2 \\
Savoy Group & YES & NO & YES & YES & YES & 4 \\
St Regis & NO & NO & YES & YES & YES & 3 \\
\hline Kempinski & NO & NO & NO & YES & YES & 2 \\
\hline GRAND TOTAL & $\mathbf{2}$ & $\mathbf{3}$ & $\mathbf{3}$ & $\mathbf{1 0}$ & $\mathbf{1 1}$ & $\mathbf{2 9}$ \\
\hline
\end{tabular}

Source: authors' contribution

Luxury brands don't use much referral marketing and affiliate marketing programs, probably due to their popularity: a luxury brand is easily recognizable (Okonkwo, 2009). Reviews are also rarely displayed on their websites and the vast majority of those available on TripAdvisor are extremely positive (based on author's observation during the empirical research, although quality score of reviews was not investigated in this research). The only exception in answering guest reviews on TripAdvisor is Hyatt.

Compared to luxury hotels, up market hotels don't use referral marketing on their websites, however the majority feature an affiliate marketing program. Less than half of them feature reviews on their official websites. All investigated chains are present on social networks and most of them answer on reviews on TripAdvisor. 
Table 4. Online Referrals Use by Up-Market European Hotels

\begin{tabular}{|c|c|c|c|c|c|c|}
\hline Brands & Referral & $\begin{array}{l}\text { Affiliate } \\
\text { Program }\end{array}$ & $\begin{array}{l}\text { Reviews on } \\
\text { Website }\end{array}$ & $\begin{array}{l}\text { Presence in } \\
\text { Social } \\
\text { Media }\end{array}$ & $\begin{array}{l}\text { Review Answer } \\
\text { on Tripadvisor }\end{array}$ & Total \\
\hline Crowne Plaza & NO & YES & YES & YES & YES & 4 \\
\hline Radisson & NO & YES & YES & YES & NO & 3 \\
\hline Swissotel & NO & YES & NO & YES & YES & 3 \\
\hline Westin & NO & YES & NO & YES & YES & 3 \\
\hline Clarion & NO & YES & YES & YES & YES & 4 \\
\hline De Vere & NO & NO & NO & YES & YES & 2 \\
\hline Firmdale & NO & NO & NO & YES & YES & 2 \\
\hline Grand Hyatt & NO & NO & NO & YES & YES & 2 \\
\hline Hilton & NO & NO & NO & YES & YES & 2 \\
\hline Hyatt Regency & NO & NO & NO & YES & YES & 2 \\
\hline Intercontinental & NO & YES & YES & YES & YES & 4 \\
\hline Jolly Master & NO & NO & NO & YES & YES & 2 \\
\hline Le Meridien & NO & NO & NO & YES & YES & 2 \\
\hline Maritim & NO & YES & NO & YES & NO & 2 \\
\hline Marriott & NO & YES & NO & YES & YES & 3 \\
\hline Mella & NO & YES & NO & YES & YES & 3 \\
\hline Millenium & NO & NO & NO & YES & YES & 2 \\
\hline Renaissance & NO & YES & NO & YES & YES & 3 \\
\hline Shangri-La & NO & NO & YES & YES & YES & 3 \\
\hline Soffitel & YES & YES & YES & YES & YES & 5 \\
\hline Sheraton & NO & YES & YES & YES & YES & 4 \\
\hline GRAND TOTAL & 1 & 12 & 7 & 21 & 19 & 60 \\
\hline
\end{tabular}

Source: authors' contribution

Table 5. Online Referrals Use by Mid-Market European Hotels

\begin{tabular}{|c|c|c|c|c|c|c|}
\hline Brands & Referral & $\begin{array}{l}\text { Affiliate } \\
\text { Program }\end{array}$ & $\begin{array}{l}\text { Reviews } \\
\text { on } \\
\text { Website }\end{array}$ & $\begin{array}{c}\text { Presence } \\
\text { in Social } \\
\text { Media }\end{array}$ & $\begin{array}{c}\text { Review } \\
\text { Answer on } \\
\text { Tripadvisor }\end{array}$ & Total \\
\hline Howard Johnson & NO & YES & NO & YES & YES & 3 \\
\hline Scandic & NO & YES & YES & YES & NO & 3 \\
\hline Novotel & NO & YES & YES & YES & YES & 3 \\
\hline Courtyard By Marriot & NO & NO & NO & YES & YES & 2 \\
\hline Country Inn By Carlson & NO & YES & YES & YES & YES & 4 \\
\hline Express By Holiday Inn & NO & NO & YES & YES & YES & 3 \\
\hline Forum & NO & NO & NO & YES & YES & 2 \\
\hline Four Points & NO & YES & YES & YES & YES & 4 \\
\hline Jolly Classic & NO & NO & NO & YES & YES & 2 \\
\hline Moat House & NO & NO & NO & YES & YES & 2 \\
\hline Quality & NO & YES & YES & YES & YES & 4 \\
\hline Ramada & NO & NO & YES & YES & YES & 3 \\
\hline Sol & NO & NO & NO & YES & YES & 2 \\
\hline Suite Hotel & NO & YES & NO & YES & YES & 3 \\
\hline Holiday Inn & NO & NO & YES & YES & YES & 3 \\
\hline Holiday Inn Garden Court & NO & NO & YES & YES & YES & 2 \\
\hline GRAND TOTAL & $\begin{array}{lll}0 \\
\end{array}$ & 7 & 9 & 16 & 15 & 47 \\
\hline
\end{tabular}

Nor mid-market hotels use referral marketing, less than half use affiliate marketing, reviews are displayed by the majority. Participation on social networks is recorded by all hotels, and almost all hotel chains provide management responses on TripAdvisor. The results are similar to up market hotels in all categories researched. 
I. Slivar - R. U. Bayer

Table 6. Online Referrals Use by Economy European Hotels

\begin{tabular}{|c|c|c|c|c|c|c|}
\hline Brands & Referral & $\begin{array}{l}\text { Affiliate } \\
\text { Program }\end{array}$ & $\begin{array}{l}\text { Reviews } \\
\text { on } \\
\text { Website }\end{array}$ & $\begin{array}{c}\text { Presence } \\
\text { in Social } \\
\text { Media }\end{array}$ & $\begin{array}{l}\text { Review } \\
\text { Answer on } \\
\text { Tripadvisor }\end{array}$ & Total \\
\hline Bastion & NO & YES & NO & YES & YES & 3 \\
\hline Campanile & NO & NO & NO & YES & YES & 2 \\
\hline Kyriad & NO & NO & NO & YES & YES & 2 \\
\hline Travelodge & NO & NO & NO & YES & NO & 1 \\
\hline Blue Marine & YES & NO & NO & YES & YES & 3 \\
\hline Comfort & NO & YES & YES & YES & YES & 4 \\
\hline Days Inn & NO & NO & YES & YES & YES & 3 \\
\hline Ibis & NO & YES & NO & YES & YES & 3 \\
\hline Innkeepers Lodge & NO & NO & NO & YES & YES & 2 \\
\hline Nuit D’hotel & NO & NO & NO & YES & YES & 2 \\
\hline Premier Lodge & NO & NO & NO & YES & YES & 2 \\
\hline Sleep Inn & NO & YES & YES & YES & YES & 4 \\
\hline Travel Inn & NO & NO & YES & YES & YES & 3 \\
\hline Wetherlodge & NO & NO & YES & NO & YES & 2 \\
\hline GRAND TOTAL & 1 & 4 & 5 & 13 & 13 & 36 \\
\hline
\end{tabular}

Referral marketing is also unpopular among economy hotel chains, followed by affiliate marketing programs and reviews on website (display less frequently than in mid-scale hotels). Most chains maintain their presence on social networking sites.

Table 7. Online Referrals Use by Budget European Hotels

\begin{tabular}{r|cccccc}
\hline \multicolumn{1}{r|}{ Brands } & Referral & $\begin{array}{c}\text { Affiliate } \\
\text { Program }\end{array}$ & $\begin{array}{c}\text { Reviews } \\
\text { on } \\
\text { Website }\end{array}$ & $\begin{array}{c}\text { Presence } \\
\text { in Social } \\
\text { Media }\end{array}$ & $\begin{array}{c}\text { Review } \\
\text { Answer on } \\
\text { Tripadvisor }\end{array}$ & Total \\
\hline Ibis & NO & NO & NO & YES & YES & 2 \\
Premiere Class & NO & NO & NO & YES & NO & 1 \\
Balladins & NO & NO & NO & NO & YES & 1 \\
\hline GRAND TOTAL & $\mathbf{0}$ & $\mathbf{0}$ & $\mathbf{0}$ & $\mathbf{2}$ & $\mathbf{2}$ & $\mathbf{4}$ \\
\hline
\end{tabular}

Source: authors' contribution

Figure 1. Online Referrals Use by European Hotels and Social Media Presence

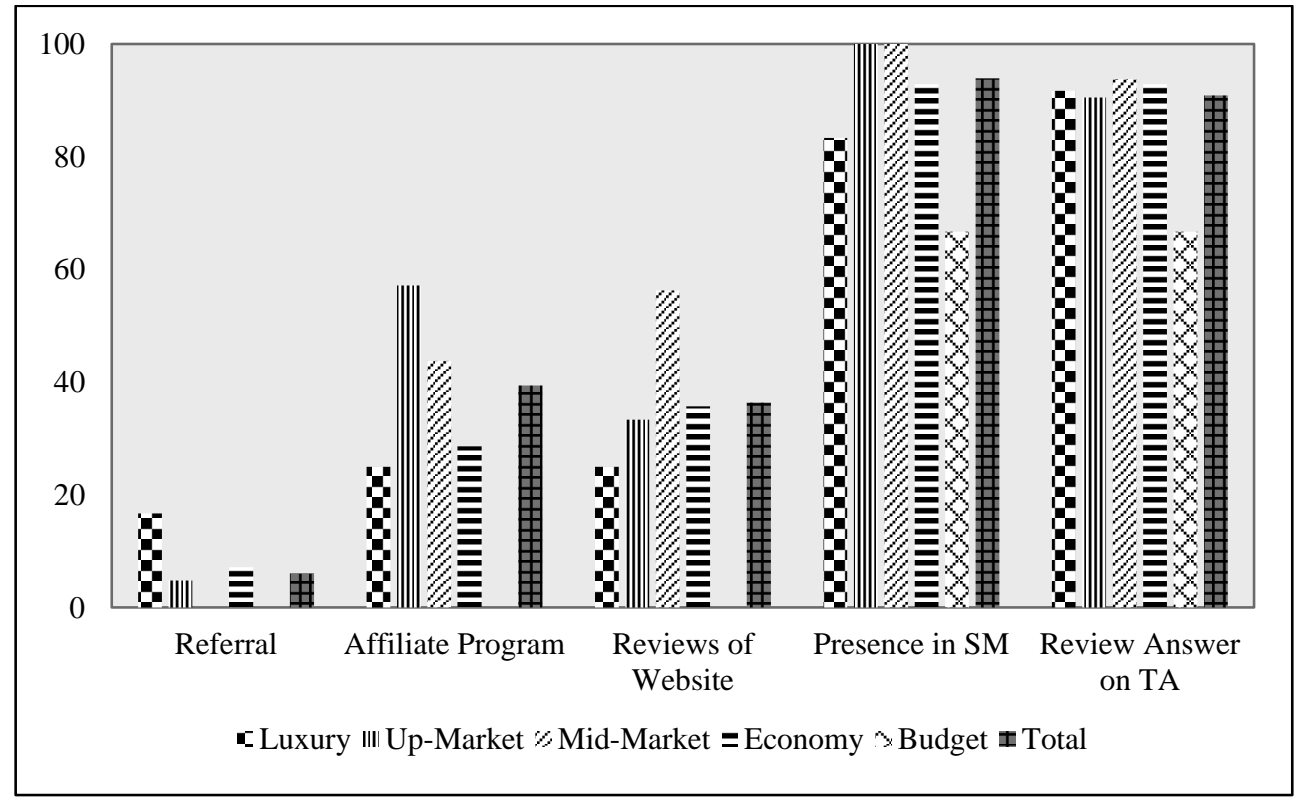


No affiliate programs, referral marketing nor reviews were found in this category of hotels. The presence on social media is quite high however not well managed (outdated contents). Obviously these hotels don't need frills but base their competitiveness on price differentiation.

Most hotel chains are present on social media networks and display links to their profiles/pages. Regarding online referrals, answering on TripAdvisor is the most common activity practiced by most (91\%), followed by affiliate marketing (40\%) and reviews on websites (36\%). Referral marketing (6\%) is almost not used at all.

It is possible to compute total online referral (TOR) score for European hotel brands with the following formula;

TOR Score $=\frac{\text { Grand Total Score }}{\text { Number of Total Observed Brands } \times 5} \times 100$

Grand total score is referred to the intercept between total and grand total in the tables 2 to 6 . The number of total observed hotel brands indicates how many hotels are listed in each category (luxury, upmarket etc.). And then, number of total observed brands is multiplied with five because there are four types of online referrals while the fifth element is social media presence (links to official profiles of hotels on various social media networks). Figure 2 is created based on this calculation.

Figure 2. Online Referral Scores of the European Hotels

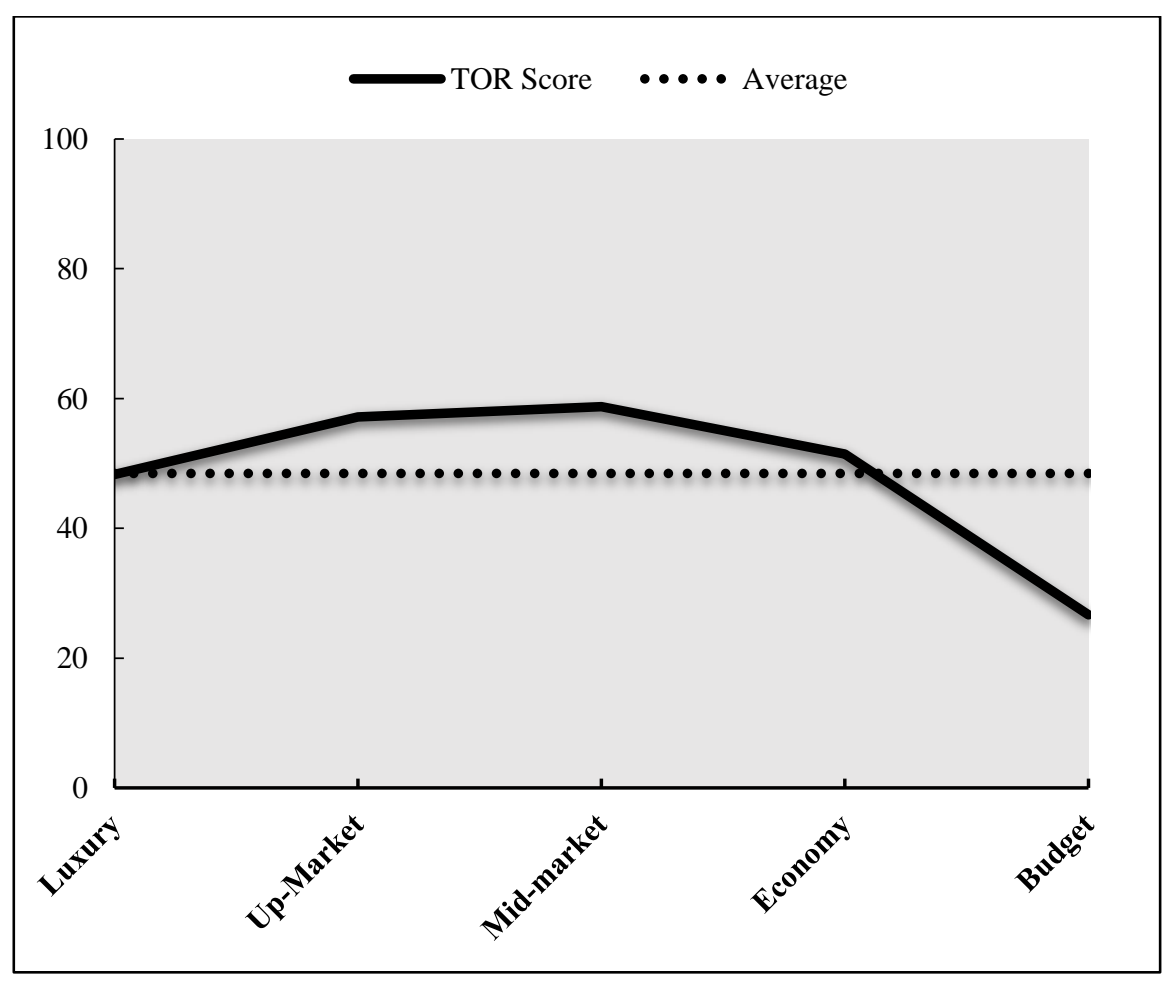

\section{Conclusion and Discussion}

The contribution of this paper is twofold. The first one lies in the theoretical amplification of online recommendations where a model classifying the many forms according to e-marketing domain is suggested. An umbrella term for the various variations, referrals, is proposed to denominate only marketing related indications or references by guests and non-intermediaries. The second derives from the research of current practices of selected international hotels brands where significantly different marketing tactics are applied in relation to hotel star classification system. 
The aim of this research was to investigate the international hotel brands in Europe in terms of their online referral marketing performance. According to the result of this research, these branded hotels (apart from budget ones) show medium-level performance in general. The most successful ones are up and midmarket, the least successful ones are those in the budget segment. The observed hotels are relatively good at social media management and responding at customers' feedbacks rather than the rest. Chan and Guillet (2011: 361-362) claimed that hotels had problems about responding their customers and it is understood that international brand hotels partially overcome that problem nowadays. These hotels' active performance in social media can be inferred as branded hotels, independently of their quality, are fairly good at keeping up with new trends. As expected, websites of hoteliers have no such infrastructure which allows visitors to share their feedback. Upon the advent of TripAdvisor and similar social rating services, the market got an independent and reliable source of information therefore; hotel guestbooks were probably deliberately dropped off because of the possibility of manipulation by hoteliers. It is known that new tourists have a positive attitude toward sharing their travel experiences voluntarily (Buhalis and Law, 2008: 612).

Affiliate marketing programs do not draw the hotels managements' interest sufficiently. It might be that hoteliers are unaware of affiliate marketing, do not perceive its benefits and/or find it too complex to manage. Such state should be investigated in depth in future researches. Also, referral marketing is the least performed technique in terms of online referrals marketing by branded hotels.

The generalization that branded European hotels show average performance in terms of online referral marketing cannot be applied to budget hotels. These hotels are just active in social media and but their performance level is below the average. Budget hotels show the worst performance in referral and affiliate marketing. It is not possible to claim that budget hotel managements are not aware of their unsuccessful performance. Managers of these hotels may have already realized this current situation but they prefer to attract customers with just concentrating on the lowering the prices. In fact, referral marketing technique is more suitable for less-known hotels and it does not require high budgets. Besides prices, potential tourists give more importance to the other tourists' reviews especially in case of less-known hotels (Vermeulen and Seegers, 2009). Although theory states that action in review management is more important for smaller hospitality establishments, our research showed that it is practiced by 2 out of 3 brands investigated.

In conclusion, the managements of international branded hotels in Europe should make a greater effort in order to increase their success level with regard to online referrals. It will not be enough to focus on just a specific field like online reviews of hotels, they have to adopt a holistic approach and strive to improve also in other categories. Online referrals are more important for smaller hotels, as explained earlier and thus those have to pay particular attention to it. From the theoretical perspective, researchers may adopt advanced quantitative analysis to data about this topic for further validation. Researchers may determine some different indicators about online referrals in their future researches in order to enhance the literature. Also, the different hotel samplings (unbranded hotels in Europe, branded hotels in Asia, America etc.) should be taken in account in future researches.

\section{References}

Bandyopadhyay, S., Wolfe, J., \& Kini, R. (2009). A critical review of online affiliate models. Journal of Academy of Business and Economics, 9(4), 141-147.

Bansal, H.S., \& Voyer, P.A. (2000). Word-of-mouth processes within a services purchase decision context. Journal of Service Research, 3(2), 166-177.

Berman, B. (2016). Referral marketing: Harnessing the power of your customers. Business Horizon, 59, $19-28$.

Bickart, B., \& Schindler, R. M. (2001). Internet forums as influential sources of consumer information. Journal of Interactive Marketing, 15(3), 31-40.

Biyalogorsky, E., Eitan, G., \& Barak, L. (2001). Customer referral management: Optimal reward programs. Marketing Science, 20(1), 82-95. 
Buhalis, D., \& Law, R. (2008). Progress in information technology and tourism management: 20 years on and 10 years after the internet-the state of e-tourism research. Tourism Management, 29, 609-623.

Buttle, F. A. (1998). Word of mouth: Understanding and managing referral marketing. Journal of Strategic Marketing, 6(3), 241-254.

Cantallops, A. S., \& Salvo, F. (2014). New consumer behavior: A review of research on e-wom and hotels. International Journal of Hospitality Management, 36, 41-51.

Chan, N. L., \& Guillet, B. D. (2011). Investigation of social media marketing: How does the hotel industry in Hong Kong perform in marketing on social media websites? Journal of Travel and Tourism Marketing, 28(4), 345-368.

Chatterjee, P. (2001). Online reviews: Do consumers use them? In M.C. Gilly \&J. Myers-Levy (Eds.), Proceedings of the ACR 2001, pp. 129-134. Provo, UT: Association for Consumer Research.

Cheung, P., Greenacre, L., \& Freeman, L. (2014). Referral types and peer activation: Who to ask? Journal of Marketing Management, 30(3-4), 295-311.

Chung, J. Y., \& Buhalis, D. (2008). Web 2.0: A study of online travel community. In: O'Connor, P., Höpken, W., Gretzel, U. (Eds.), Information and Communication Technologies in Tourism, Springer, Vienna, Austria. pp. 70-81.

Cox, C., Burgess, S., Sellitto, C., \& Buultjens, J. (2011). Consumer generate media in hospitality and tourism: Travellers' likes and their concerns about the latest innovation in hospitality marketing. ICHLAR 2011: International Conference on Hospitality \& Leisure Applied Research, Lyon, France.

Daniele, R., Frew, A. J., Varini, K., \& Magakian, A. (2009). Affiliate marketing in travel and tourism. Information and Communication Technologies in Tourism (ICTT), pp. 343-354.

De Matos, C.A., \& Rossi, C.A.V. (2008). Word of mouth communications in marketing: A meta-analytic review of the antecedents and moderators. Journal of the Academy of Marketing Science, 36, 578-596.

Dellarocas, C. (2003). The digitization of word-of-mouth: Promise and challenges of online feedback mechanisms. Management Science, 49(10), 1407-1424.

Duffy, D. L. (2005). Affiliate marketing and its impact on e-commerce. Journal of Consumer Marketing, 22(3), $161-163$.

Filieri, R., \& McLeay, F. (2013). E-wom and accommodation: An analysis of the factor that influence travelers' adoption of information from online reviews. Journal of Travel Research, 53(1), 44-57.

Garnefeld, I., Eggert, A., Helm, S. V., \& Tax, S. S. (2013). Growing existing customers' revenue streams through customer referral programs. Journal of Marketing, 77(4), 17-32.

Gregori, N., Daniele, R., \& Altinay, L. (2014). Affiliate marketing in tourism: Determinants of consumer trust. Journal of Travel Research, 53(2), 196-210.

Gretzel, U., \& Yoo, U. (2008). Use and impact of online travel reviews. In: O'Connor, P., Höpken, W., Gretzel, U. (Eds.), Information and Communication Technologies in Tourism, Springer, Vienna, Austria. pp. 35-46.

Jeong, M., \& Jeon, M. M. (2008). Customer reviews of hotel experiences through Consumer Generated Media (CGM). Journal of Hospitality and Leisure Marketing, 17(1-2), 121-138.

Kaplan, A. M., \& Haenlein, M. (2010). Users of the world, unite! The challenges and opportunities of social media. Business Horizon, 53, 59-68.

Kornish, L. J., \& Quiping, L. (2010). Optimal referral bonuses with asymmetric information: Firm-offered and interpersonal incentives. Marketing Science, 29(1), 108-121.

Kumar, V., Petersen, J. A., \& Leone, R. P. (2010). Driving profitability by encouraging customer referrals: Who, when and how. Journal of Marketing, 74(5), 1-17.

Lewis, M. (2006). Customer acquisition promotions and customer asset value. Journal of Marketing Research, 43, 195203.

Litvin, S. W., \& Hoffman, L. M. (2012). Responses to consumer-generated media in the hospitality marketplace: An empirical study. Journal of Vacation Marketing, 18(2), 135 -145.

Litvin, S. W., Goldsmith, R. E., \& Pan, B. (2008). Electronic word-of-mouth in hospitality and tourism management. Tourism Management, 29, 458-468.

Looker, A., Rockland, D., \& Taylor-Ketchum, E. (2007). Media myths and realities: A study of 2006 media usage in America. Public Relations Tactics, Retrieved from: https://www.prsa.org/SearchResults/view/1055/105/Media_myths_and_realities_A_study_of_2006_media_us \#.VwT3HZyLRQI 
Mariussen, A., Daniele, R., \& Bowie, D. (2010). Unintended consequences in the evolution of affiliate marketing networks: A complexity approach. The Service Industries Journal, 30(10), 1707-1722.

O'Connor, P. (2010). Managing a hotels' image on TripAdvisor. Journal of Hospitality Marketing and Management, 19(7), 754-772.

Okonkwo, U. (2009): The luxury brand strategy challenge. Journal of Brand Management, 16, 287-289

Park, D.H., Kim, S., \& Han, J. (2007). The effects of consumer knowledge on message processing of electronic word of mouth via online consumer reviews. ECIS 2007, June 7-9, St. Gallen, Switzerland.

Pearse, J. (2007). Learning to trust consumers' views. New Media Age, 16 December, 16.

Poon, A. (1993). Tourism. Technology and competitive strategies. Oxon: CABInternational.

Schmitt, P., Skiera, B., \& Bulte, C. V. D. (2011). Referral programs and customer value. Journal of Marketing, 75, $46-59$.

Schuckert, M., Liu, X., \& Law, R. (2015). Hospitality and tourism online reviews: Recent trends and future directions. Journal of Travel \&Tourism Marketing, 32(5), 608-621.

Sheldon, P. J. (1997). Tourism information technology. New York: Cab International.

Smith, D., Menon, S., \& Sivakumar, K. (2005). Online peer and editorial recommendations, trust and choice in virtual markets. Journal of Interactive Marketing, 19(3), 15-37.

Statisticbrain, (2014). Internet Travel Hotel Booking Statistics. Retrieved from: http://www.statisticbrain.com/internettravel-hotel-booking-statistics/

Stringam, B. B., \& Gerdes, J. (2010). An analysis of word-of-mouse ratings and guest comments of online hotel distribution sites. Journal of Hospitality Marketing and Management, 19(7), 773-796.

Ugbah, S. D., \& Evuleocha, S. U. (2007). Referral marketing networks: Description, utility, and managerial implications. Proceedings of the Academy of Marketing Studies, 12(1), 51-55.

Verlegh, P. W. J., Ryu, G., Tuk, M. A., \& Feick, L. (2013). Receiver response to rewarded referrals: The motive inferences framework. Journal of the Academic Marketing Sciences, 41, 669-682.

Vermeulen, I. E., \& Seegers, D. (2009). Tried and tested: The impact of online hotel reviews on consumer consideration. Tourism Management, 30, 123-127.

Wang, Y. S., \& Tang, T. (2003). Assessing customer perceptions of web site service quality in digital marketing environments. (Chapter 2). In M. Adam Mahmood, El Paso (Eds.), Advanced Topics in End User Computing.

Wertime, K., \& Fenwick, I. (2008). DigiMarketing: The essential guide to new media and digital marketing (1th. Ed.). New Jersey: John Wiley \& Sons.

Xia, P., Tang, C. S., \& Wirtz, J. (2011). Optimizing referral reward programs under impression management considerations. European Journal of Operational Research, 215, 730-739.

Xiang, Z., \& Gretzel, U. (2010). Role of social media in online travel information search. Tourism Management, 31, 179188.

Yoo, K.H., \& Gretzel, U. (2010). Antecedents and impacts of trust in travel- related consumer generated media. Journal of Information Technology \&Tourism, 12(2), 139-152. 
This Page Intentionally Left Blank 